DOI: https://doi.org/10.34069/AI/2021.46.10.19

How to Cite:

Shulzhenko, F.P., Ryndiuk, V.I., Kuzmenko, O.V., Kozhura, L.O., \& Gryshko, O.M. (2021). Transformation of the national legislation of Ukraine in the context of globalization. Amazonia Investiga, 10(46), 191-200. https://doi.org/10.34069/AI/2021.46.10.19

\title{
Transformation of the national legislation of Ukraine in the context of globalization
}

\section{Трансформація національного законодавства України в умовах глобалізації}

\author{
Received: July 12, 2021
}

Accepted: September 30, 2021

\begin{abstract}
The article studies the directions of transformation of the national legislation of Ukraine in the context of globalization based on the dialectical method. Specifically, the notions "legislation" and "globalization" are analyzed; the meaning of the concepts of "national legislation of Ukraine" and "legal globalization" is specified; the factors which define features of transformation of the national legislation of Ukraine in modern conditions of globalization are established. As a result of the study it is proved that the main directions of transformation of the national legislation of Ukraine in the conditions of globalization are the following: borrowing the European (Western) legal tradition and its adaptation to the national legal system of Ukraine; reception of innovative legal institutions while preserving the national legal tradition; the influence of international law, first of all, the Acquis communautaire (adaptation of the national legislation of Ukraine to the law of the European Union); hierarchical (vertical) and
\end{abstract}

\section{Анотація}

В статті досліджуються напрямки трансформації національного законодавства України в умовах глобалізації на основі діалектичного методу. Зокрема, аналізуються поняття "законодавство" та "глобалізація"; уточнюється зміст понять "національне законодавство України" та “правова глобалізація"; встановлюються чинники, які визначають особливості трансформації національного законодавства України в сучасних умовах глобалізації. У результаті дослідження доведено, що основними напрямами трансформації національного законодавства України в умовах глобалізації $\epsilon$ наступні: запозичення європейської (західної) правової традиції та їі адаптація до національної правової системи України; рецепція інноваційних правових інститутів при збереженні національної правової традиції; вплив міжнародного права, в першу чергу, Acquis communautaire (адаптація національного законодавства України до

\footnotetext{
${ }^{74}$ Doctor of Science in Philosophy, Professor, Head at the Department of Theory and History of Law, Kyiv National Economic University named after Vadym Hetman, Kyiv, Ukraine.

${ }^{75}$ Candidate of Science in Law, Associate Professor, Professor at the Department of Theory and History of Law, Kyiv National Economic University named after Vadym Hetman, Kyiv, Ukraine.

${ }^{76}$ Doctor of Science in Law, Professor, Head at the Department of Administrative and Financial Law, Kyiv National Economic University named after Vadym Hetman, Kyiv, Ukraine.

${ }^{77}$ Doctor of Science in Law, Associate Professor, Professor at the Department of Theory and History of Law, Kyiv National Economic University named after Vadym Hetman, Kyiv, Ukraine.

${ }^{78}$ Candidate of Science in Law, Associate Professor, Professor at the Department of Theory and History of Law, Kyiv National Economic University named after Vadym Hetman, Kyiv, Ukraine.
} 
sectoral (horizontal) structure of legislation, which is characteristic of the legal systems of the Romano-Germanic legal family; development of such types of normative activity of public authorities as systematization, codification, ordering, unification, etc.

Keywords: globalization, internationalization of law, legal family, legal system, legal tradition, legislation, reception of law.

\section{Introduction}

The national legislation of any state is one of the external forms of expression of law, a way of formally establishing and ensuring the norms and principles of law by which the relations between people and their associations in a particular society are regulated. The legal system of Ukraine is correlated with the Romano-Germanic legal family, therefore the national legislation of Ukraine is the main specific form of external expression of law in Ukraine. First of all, national legislation is formed under the influence of political, economic, social and other processes that take place within the country and require legal regulation at the state level. However, the objective reality of today is globalization, which has its impact on all spheres of human society, in particular, on the sphere of law. In this regard, legal globalization is one of the factors that affect the national legislation of Ukraine and determine the characteristics of its development. All of the above determines the relevance of the chosen research topic.

The purpose of the article is to establish and analyze the main directions of transformation of the national legislation of Ukraine in the context of globalization. To achieve this goal, the following tasks are solved: the meaning of the terms "national legislation of Ukraine" and "legal globalization" is specified; globalization factors, that affect the peculiarities of the development of national legislation of Ukraine in modern conditions, are determined; the main directions of transformation of the national legislation of Ukraine connected with legal globalization are analyzed.

\section{Literature Review}

The peculiarity of this study is that it is based on the dialectical theory of law proposed and developed in detail by Yushchyk (2013) in the scientific work "Dialectics of Law" and others права Європейського Союзу); ієрархічна (вертикальна) та галузева (горизонтальна) будова законодавства, яка характерна для правових систем романо-германської правової сім'і; розвиток таких видів нормотворчої діяльності органів публічної влади як систематизація, кодифікація, упорядкування, уніфікація тощо.

Ключові слова:
iнтернаціоналізація права, правова сім'я,
правова система, правова традиція,
законодавство, рецепція права.

(Yushchyk, 2016), which, in fact, is a variant of sociological understanding of law, based on the dialectical method.

At the present stage of development of legal science, which is characterized by the need for scientific understanding of the development of law in the context of globalization processes, there are a significant number of scientific papers which examines the impact of globalization on the legal system of Ukraine as a whole. The impact of globalization on the sphere of law is also studied by foreign researchers: Beinoravicius (2018), Rasskazov (2015), Nykytyna (2008), Westbrook (2006) and others. The national legislation of Ukraine is the main normative (regulatory) component of the national legal system of Ukraine, therefore, the relevant globalization factors determine the features of the transformation of national legislation of Ukraine. In this study were analyzed following scientific works of Ukrainian authors who study the features of the impact of globalization on law: Mernyk \& Burlakov (2019), Biriukova (2018), Biryokov (2011), Khaustova (2015), Nastasyak (2014), Sobkova (2012) and others.

\section{Methodology}

The basis of the research methodology is the dialectical method, which provides for the need for a comprehensive study of national legislation as a phenomenon that is in dynamics and constant renewal, in particular, changes under the influence of a set of factors that determine globalization processes. Based on the dialectical theory of law and using the dialectical method, in the article it is offered understanding of the concept of national legislation of Ukraine and identifies the main directions of transformation of national legislation of Ukraine under the influence of globalization. 


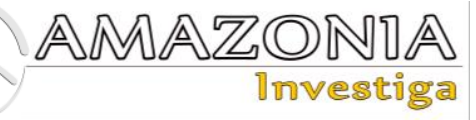

The method of ascent from the abstract to the concrete (deduction) is used, which makes it possible to move from general conclusions to relatively specific ones. This method allowed to analyze the specific features of the national legislation of Ukraine, based on the general features that characterize the place and role of legislation in the national legal systems of the Romano-Germanic legal family.

The use of such categories of dialectics as "general", "special" and "single" allowed to study the relationship between the national legislation of Ukraine and the law of the European Union in the process of adapting the legislation of Ukraine to the Acquis communautaire.

Also in the course of the research a formal-legal method was used, which allowed to analyze the national legislation and draw conclusions about the peculiarities of the influence of globalization factors on the transformation of the national legislation of Ukraine.

\section{Results and Discussion}

In the theory of law and legal practice, the scope of the concept of "legislation" is not unambiguous; this raises both scientific discussions on this issue and problems in the areas of lawmaking and law enforcement. Analysis of the definitions of "legislation", which are given in the literature and normative legal acts, allows us to conclude that "legislation" is understood as a set of laws, other normative-legal acts or other sources of law, in particular, international agreements. The main discussion is around the next question: what normative-legal acts or other sources of law to include this concept and which are not.

Any source of law is a recognized in a particular society official form of external expression and establishment of norms of law (Petryshyn, 2015). Norms of law find their external expression in such sources of law as normative-legal act, normative-legal contract, legal precedent and legal custom. Ryndiuk (2021) explores the problem of interpreting the concept of "legislation" in the context of understanding the law and concludes: in the set of sources of law should be distinguished legislation as a set of normative-legal acts that are an external expression of the norms of law established by public authorities. In the dialectical theory of law, the norms of law are considered as one of the types of social norms - the rules of conduct of people, the implementation of which is ensured by a certain authority (internal or external). The subject of the norms of law is only the rules of behavior of real participants in communication with each other, in which one of the participants is the subject of the claim, and the other is the subject of satisfaction of this claim. These rules of behavior become norms of law by recognizing them as a certain external authority (in particular, public authorities, corporate governance, etc.) necessary (mandatory) in the process of specific management sanctioning (rule-making) activities. The result of rule-making activities of public authorities is "legislation" - a set of management decisions of public authorities in the form of normative-legal acts, which express the rules of behavior recognized by the state as necessary and therefore provided by its force (sanction). National legislation of Ukraine is only one of the forms (the main specific form) of external expression of norms of law in normative-legal acts of public authorities, those law norms that are recognized as necessary (sanctioned) by the state as an authoritative subject; that is, those law norms that have become legal (juridical) norms.

The legislation of any state is a hierarchical system of management decisions of public and local authorities, which have a normative character, that is, are normative-legal acts (Ryndiuk, 2019). Public authorities, within the limits of their powers, adopt normative-legal acts, that constitute the national legislation of Ukraine, in forms clearly defined by the Constitution of Ukraine and laws of Ukraine. The national legislation of Ukraine is the following hierarchical system of normative-legal acts: the Constitution of Ukraine and constitutional laws (laws amending the Constitution of Ukraine); international agreements ratified by the Verkhovna Rada of Ukraine (laws of Ukraine on ratification of international agreements); laws of Ukraine; decrees of the President of Ukraine of normative character; resolutions of the Verkhovna Rada of Ukraine of normative content; resolutions of the Cabinet of Ministers of Ukraine; orders of the ministries of normative character which have passed the state registration in the Ministry of Justice of Ukraine; normativelegal acts of local state administrations which have passed the state registration in the relevant bodies of justice; decisions of normative character of local governments. Thus, the Constitution of Ukraine has the highest legal force. Laws and other normative-legal acts are adopted on the basis of the Constitution of Ukraine and must comply with it (Article 8 of the Constitution of Ukraine). 


\section{Impact of globalization on the legal system of Ukraine}

The concept of globalization in general is associated with the process of interconnection of countries and peoples in all spheres of society (economy, politics, law, culture, social spheres, ideology, etc.), which leads to the realization of the world as a whole, where all countries and peoples are subject to the law of interchange, cooperation and interdependence (Rasskazov, 2015). Legal globalization should be understood as a relatively independent phenomenon that expresses the transformation processes that at the interstate level (macro level) contribute to the formation of a global system of law norms, as a necessary condition and organizational basis for interstate cooperation in various spheres of social life (Biriukova, 2018). Thus, in the sphere of law globalization manifests itself in the convergence of legal systems of states, strengthening their interaction and influence, the formation of supranational (interstate) legal systems.

National legislation as a central normative (regulatory) component of the legal system of Ukraine inevitably changes under the influence of globalization. Mernyk \& Burlakov (2019) write that the national legal system is significantly affected by the globalization process, which is due to both subjective and objective factors. An objective factor influencing globalization on the legal system of Ukraine is the geographical location of the country, which is characterized by the location of the territory of Ukraine within the European continent and makes it impossible to isolate the Ukrainian legal system from European legal life, not involving Ukraine in interaction, cooperation with other European countries. The subjective factor is related to the constitutional consolidation of the European vector of state and legal development of Ukraine.

The analysis of scientific works, which examines the impact of globalization on the legal system of Ukraine as a whole and the legal practice, made in the article, makes it possible to identify the following directions of transformation of national legislation of Ukraine in the context of globalization.

First, it is the impact on the development of national legislation of Ukraine of European (Western) legal tradition. Vovk (2012) notes that the legal tradition occupies a central place in the characterization of law as a civilizational phenomenon and a component of the culture of a society. Given the geopolitical position of
Ukraine, the legal system and national legislation of Ukraine are developing under the influence of European (Western) legal tradition, that is, those legal values, categories and institutions that are inherent in Western European civilization. In particular, such legal values are European standards in the sphere of human rights, democracy, rule of law, legal and social state, the principle of separation of powers, a developed institution of private property, which plays a crucial role in the economic life of society, etc.

These legal values, theories and concepts are further developed in Ukrainian legal science in the context of the national legal system. Khaustova (2015) writes that the improvement of the ideological component of the legal system is as follows: participating in legal globalization, the national legal system is filled with new ideas, doctrines, views; the level of legal culture and consciousness is growing, which contributes to the legal awareness of the population, increasing the level of effectiveness of law, and legal regulation. In particular, these are ideas related to human rights, the rule of law, a friendly attitude to international law, etc.

For example, Shulzhenko (2007) explores the theoretical and practical problems of the formation of a social and legal state in Ukraine, and also proposes to introduce into scientific circulation the term "social-lawful" state. According to the scientist, the official authorities do not pay due attention to the recommendations of scientists and prefers empirical methods of reform, mainly based on the experience of Western countries. This does not take into account the fact, that Ukrainian society has encountered problems unknown to Western democracies.

These legal values were enshrined in the Constitution of Ukraine, and were further developed in the national legislation of Ukraine. Ukraine is a sovereign and independent, democratic, social, legal state (Article 1 of the Constitution of Ukraine). A person's life and health, honor and dignity, inviolability and security are recognized in Ukraine as the highest social value. Human rights and freedoms and their guarantees determine the content and direction of the state. The state is responsible to the people for its activities. The assertion and provision of human rights and freedoms is the main duty of the state (Article 3 of the Constitution of Ukraine). State power in Ukraine is exercised on the basis of its division into legislative, executive and judicial (Article 6 of the Constitution of Ukraine). In Ukraine, the 


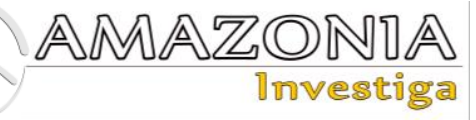

principle of the rule of law is recognized and operates (Article 8 of the Constitution of Ukraine).

Secondly, it is the influence on the national legislation of Ukraine of the defining features of the Romano-Germanic legal family, with which the national legal system of Ukraine is correlated. The national legal system of each state (including Ukraine) is unique (from the point of view of dialectics - single) and includes all legal phenomena that exist within a particular state. At the same time, legal science unites national legal systems into legal families according to common defining criteria. Zavalnyi, Tiurina, Kryvytskyi \& Pidvysotskyi (2017) note that the typology of national legal systems contributes to harmonization and unification processes in law, and is also a scientific basis for adequate borrowing of positive legal experience to improve the domestic legal system. The special practical significance of the typology of modern legal systems is manifested in the possibility of using its scientific potential to borrow positive legal experience in order to improve certain elements of the domestic legal system, in particular national legislation.

In the context of globalization there is a convergence of different legal families and their components. There are the following legal families: Anglo-Saxon (common law family), continental (Romano-Germanic), traditional law family and religious. Nastasyak (2014) notes that the brightest impact of globalization can be traced in continental and common law - within the Romano-Germanic and Anglo-Saxon legal systems and in the connections between them. The convergence of the Romano-Germanic and Anglo-Saxon legal systems is due to a number of circumstances, including the following: the affiliation of most states of continental and common law to the tradition of Western democracy, similarity of their general and legal culture, uniformity of economy, social and political structure of society, the presence in these legal systems of numerous nongovernmental institutions that significantly influence the development of law.

Luts (2005), Hapotii et al, (2019), Mernyk \& Burlakov (2019) and other researchers correlate the national legal system of Ukraine with the Romano-Germanic legal family, therefore, the national legal system of Ukraine is characterized by all the defining common features of this legal family. Thus, the national legislation of Ukraine, as the main specific form of external expression of legal norms in Ukraine, is characterized by its individual unique features, and has common features of the Romano-Germanic legal family. Such common features are: 1) recognition of a normative-legal act of public authorities as the main source of law and a corresponding understanding of legislation as a set of normative-legal acts of public authorities; 2) hierarchical (vertical) structure of legislation, determined by the legal force of normative-legal acts; 3) sectoral (horizontal) structure of legislation, determined by the division of law into public and private, as well as the sectoral structure of law. Such identifying features of the Romano-Germanic legal family as the codified and unified character of law, presupposes the need for such types of rule-making activities of public authorities in Ukraine - unification, systematization, ordering, consolidation, codification of legislation, etc.

As the third direction of transformation of the national legislation of Ukraine in the context of globalization it is possible to name reception of law while preserving the national legal tradition. Nykytyna (2008) writes that the historical main direction of globalization in the sphere of law is the reception of law. Reception is a borrowing, the perception of the national law of one state of the principles, institutions, norms of another state. By borrowing regulations and legal institutions of other states, uniformity is achieved in the legal regulation of similar groups of public relations in different countries. Globalization in the sphere of law is impossible without reception, which is manifested in modern conditions in different ways and contributes, ultimately, to the rapprochement of legislations of different states. However, reception can give unwanted effects and lead, ultimately, to the rejection of borrowed institutions adopted without regard to the traditional cultural foundations of national law.

Biryokov (2011) notes that on the one hand, the modern world is characterized by the universalization of law, which is a manifestation of globalization processes and is reflected in the desire to develop a common comprehensive approach to law, which means introducing the same norms into national legal systems. On the other hand, there is a phenomenon of identity of national law as a significant and constant manifestation of those components of cultural heritage of any society, which are functionally necessary for its continued existence, ensure its self-preservation and identity with all changes in the normative-value and substantive spheres. Identity is the basis for preserving the principles of socio-cultural regulation inherent in every society. The identity of the national legal system 
reflects the specifics of the national legal consciousness, legal culture, dominant legal understanding, legal mentality, due to the national legal tradition, values in each individual society.

Thus, globalization in the sphere of law is impossible without the reception of law, which contributes to the universalization and unification of law, and, as a consequence, the approximation of legislations of different states. The reception of law is an invariable tool for the development of national law. The experience gained by other peoples is an inexhaustible source of great benefit and greatly facilitates legal reforms. Moreover, in the modern period of globalization, the reception of law makes it possible to adequately respond to the challenges of the time by borrowing legal innovations that have been tested in other countries and can improve their own legal system. However, the reception of law requires a careful, cautious approach and careful preliminary study from the standpoint of taking into account the social context of the recipient country. Uncritical implementation of foreign legal institutions incapable of adequate assimilation may deepen the crisis of legality and instead of the necessary solution of relevant issues cause additional problems of the domestic legal system Homonai (2012). For example, in the post-soviet period there was a "revival" of the reception of Roman law, which brought new or updated institutions of private law into the country's legal system: a legal entity, a marriage contract, compulsory civil liability insurance of motor vehicle owners, etc. (Rasskazov, 2015).

The fourth direction of transformation of the national legislation of Ukraine in the conditions of globalization is the influence on the development of the national legislation of international law and international legal systems, that is, the internationalization of law. International law is a system of principles and norms of law that govern the relationship between states and other actors in the international community. In today's globalized world, not only individual states have a legal system (national legal systems), but also various political interstate entities (interstate legal systems). Luts (2005) notes that the emergence of the interstate legal system is due to the objective patterns of modern development of humanity, in particular, such as: expanding the range of subjects of international relations, increasing their number; complication of international relations; recognition of a number of human problems as global; the need to change legal means and establish their adequacy for the purposes of international legal regulation; the growing role of law in the settlement of international relations. Interstate legal systems are able to solve previously unknown in scope and complexity of tasks, primarily those that national legal systems are unable to solve by domestic means. Biryokov (2009) writes that the existence of global problems facing humanity determines the admissibility and possible limits of supranational. Global supranational legal regulation is required by those issues that are relevant to the interests of the entire international community. Important in the further universalization of domestic law is the consolidation in the national constitutions of the modern complex of inalienable natural human rights and freedoms, and recognition of universally recognized principles and norms of international law as a priority component of the national legal system.

Thus, in the current conditions of globalization, constant political, economic, social interstate cooperation, the national legislation of states inevitably develops under the influence of international law. Given the changes taking place in the world, the issues to be addressed by the modern state can often not be limited to its own sovereignty and territory (for example, economic, environmental, cultural problems). Rasskazov (2015) notes that globalization has an impact on state sovereignty. In the context of globalization, the process of voluntary limitation of state sovereignty by mutual agreement with other States, but, at the same time, the process and the empowerment of its sovereignty, because the state has the authority to participate in solving problems that were not in the scope of its sovereignty. Globalization affects the law of all modern countries; the relationship between national and international law increases, strengthening the position of the international law. This process can be named with the term of "internationalization" in the legal literature. Khaustova (2013) says that internationalization means the convergence of national political and legal systems, which leads to increased their interaction and collaboration. Such convergence contributes to the fact that similar legal situations are resolved more efficiently and quickly.

In modern conditions, the influence of international law on the functioning of national legal systems is increasing. In the context of globalization, a nation-state is forced to submit to norms created without its participation and consent, on the basis of the powers delegated by it in advance to international organizations or 


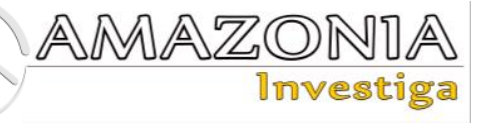

regional associations. In particular, in the context of globalization, the concept of human and citizen rights and freedoms is subject to significant change, increasing trends in their standardization. Determining in this regard are the issues of guarantees of their implementation and compliance, which are provided at the national-state and global levels. The problem of human rights and freedoms has ceased to be only an internal affair of the state and has reached the supranational level of legal regulation (Biryokov, 2011).

According to Article 18 of the Constitution of Ukraine, Ukraine's foreign policy is aimed at ensuring its national interests and security by maintaining peaceful and mutually beneficial cooperation with members of the international community in accordance with generally accepted principles and norms of international law. Globalization processes are mediated in national legislation through state participation in international organizations and the conclusion of international agreements; recognition of the priority of international law over national; harmonization of national legislation with the principles and norms of international law. Sobkova (2012) notes that legal globalization involves the formation of a supranational system of legal regulation of life of society. In practice, this means, first of all, the adaptation of national legislation to harmonized international legal norms and rules; giving priority to international legislation over national ones. Unification of the current national legislation takes place, universal (general) international and regional law is formed.

The Declaration of State Sovereignty of Ukraine of July 16, 1990 establishes the priority of universally recognized norms of international law over norms of domestic law. In accordance with Article 9 of the Constitution of Ukraine, existing international agreements, the binding nature of which has been approved by the Verkhovna Rada of Ukraine, are part of the national legislation of Ukraine. The conclusion of international agreements that contradict the Constitution of Ukraine is possible only after the relevant amendments to the Constitution of Ukraine. The Law of Ukraine "On International Agreements of Ukraine" of June 29, 2004 (as amended) states that if an international agreement of Ukraine, which has entered into force in the prescribed manner, establishes rules other than those provided for in the relevant act of legislation of Ukraine, then the rules of the international agreement apply (Article 19).
In the process of globalization there is a unification of states and the creation of influential intergovernmental organizations, the formation of their legal systems, such as the Council of Europe and the European Union. The national legislation of Ukraine is primarily being transformed under the influence of the European interstate legal systems of the Council of Europe and the European Union, which play a significant role in the formation of a single European space and universally European legal standards.

On November 9, 1995, Ukraine became a member of the leading organization for the protection of human rights on the continent - the Council of Europe, and took a number of commitments to reform current legislation on the basis of norms and standards of the Council of Europe. These standards were enshrined in the Constitution of Ukraine, adopted on June 28, 1996, and the current legislation of Ukraine. Also, on July 17, 1997, Ukraine ratified the Convention for the Protection of Human Rights and Fundamental Freedoms (European Convention on Human Rights (ECHR)). A separate institution of the Council of Europe, which was created to monitor the observance of human rights and freedoms, enshrined in the Convention for the Protection of Human Rights and Fundamental Freedoms, is an international court - the European Court of Human Rights. According to Article 17 of the Law of Ukraine "On the Fulfillment of Decisions and Application of Practice of the European Court of Human Rights" of 23 February 2006, the courts apply the Convention for the Protection of Human Rights and Fundamental Freedoms and the case law of the European Court of Human Rights as a source of law. Thus, the precedents, set by the European Court of Human Rights, are a source of law in Ukraine and have an impact on the development of national legislation of Ukraine.

The European Commission for Democracy through Law (The Venice Commission) is a universally recognized European and world legal advisory body of the Council of Europe on constitutional law, which provides conclusions on compliance of draft legislative acts with European standards and values. Ukraine cooperation with the Venice Commission is a permanent and effective form of using the scientific and expert potential of the Council of Europe to improve national legislation in accordance with European standards (Ministry of Foreign Affairs of Ukraine, 2019a). The Venice Commission is composed of independent experts who have received international recognition for their experience in democratic institutions or for 
their contribution to the strengthening of law and the development of political science. The decisions of the Commission are not legally binding and are consultative character. However, such conclusions are mainly taken into account by public authorities in the preparation of final texts of acts of constitutional legislation (Ministry of Foreign Affairs of Ukraine, 2019b). Over the years of its existence, the Venice Commission has prepared more than 150 opinions and expert assessments on draft laws and laws of Ukraine (Permanent Representation of Ukraine to the Council of Europe, 2020).

Given Ukraine's chosen course of European integration and accession to the European Union, the legal system of the European Union (Acquis communautaire (acquis)) has a priority influence on the development of national legislation of Ukraine. The Association Agreement between the European Union and the European Atomic Energy Community and their member states, of the one part, and Ukraine, of the other part (hereinafter - the Association Agreement) was ratified by the Law of Ukraine of September 16, 2014. Also on February 21, 2019, the relevant amendments were made to the Constitution of Ukraine (The Law of Ukraine "On Amendments to the Constitution of Ukraine (regarding strategic course toward full membership of Ukraine in the European Union and North Atlantic Treaty Organization)" on February 7, 2019). The Basic Law of Ukraine enshrines norms that confirm the European identity of the Ukrainian people and the irreversibility of the European and Euro-Atlantic course of Ukraine; Ukraine's strategic course for full membership in the European Union and the North Atlantic Treaty Organization (NATO). In this regard, the issues of adaptation of Ukrainian legislation to the legislation of the European Union are relevant.

Article 114 of the Association Agreement states that the parties recognise the importance of the approximation of Ukraine's existing legislation to that of the European Union. Ukraine shall ensure that its existing laws and future legislation will be gradually made compatible with the EU acquis. Such approximation will start on the date of signing of this Agreement, and will gradually extend to all the elements of the EU acquis referred to in Annex XVII to this Agreement. The concept of "adaptation of legislation" was defined in the Law of Ukraine "On the National Program for Adaptation of Legislation of Ukraine to the Legislation of the European Union" of March 18, 2004 (as amended) as a process of bringing the laws of Ukraine and other normative legal acts in line with the acquis communautaire (European Union law). Thus, the adaptation of legislation is a unilateral process of approximation and gradual alignment of national legislation of Ukraine in accordance with the legislation of the European Union (acquis). Regarding the degree of approximation of the national legislation of Ukraine to the legislation of the European Union, in Article 2 of Annex XVII "Regulatory approximation" to the Association Agreement defines the general principles of normative-legal approximation of the legislation of Ukraine. Thus, 1) if an act corresponding to a EU Regulation or Decision shall as such be made part of the internal legal order of Ukraine; 2) if an act corresponding to a EU Directive shall leave to the authorities of Ukraine the choice of form and method of implementation.

Accordingly, the peculiarities of the relationship of the national legislation of Ukraine with the legislation of the European Union can be considered through such categories of dialectics as general, special and singular. Singular in this case are unique, individual, specific, special norms of current legislation of Ukraine. The legislation of the European Union is general. In the process of adapting the legislation of Ukraine to the law of the European Union, a task appears: to combine the singular (Ukrainian legislation) with the general (acquis) through the mediating link, namely through the special. The legal principles and norms of the European Union legislation, to which the legislation of Ukraine must be adapted, will be special.

Moroz (2020) writes that in the formation of the national legal system in accordance with EU norms, it is necessary, simultaneously with the approximation of existing laws, to adopt new laws that is consistent with EU law. According to the current legislation of Ukraine, all draft normative-legal acts adopted by public authorities in Ukraine, is the subject of legal examination for compliance with European Union law. For example, in accordance with Article 93 of the Law of Ukraine "On the Rules of Procedure of the Verkhovna Rada of Ukraine" of February 10, 2010 (as amended), each draft law is sent to the committee of the Verkhovna Rada of Ukraine, which is responsible for assessing the compliance of draft laws with Ukraine's international legal obligations in the sphere of European integration, to prepare an appropriate expert opinion. Also, in accordance with $\S 35$ of the Rules of Procedure of the Cabinet of Ministers of Ukraine (as amended by the Resolution of the Cabinet of Ministers of 


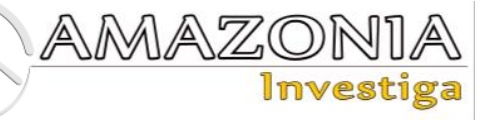

Ukraine of November 9, 2011 (as amended)), acts of the Cabinet of Ministers are subject to elaboration for compliance with Ukraine's obligations in the sphere of European integration, including international law, and taking into account the law of the European Union (EU acquis).

\section{Conclusions}

As a result of the study, we can identify the following four directions of globalization impact on the national legislation of Ukraine:

1) development of national legislation of Ukraine under the influence of European (Western) legal tradition;

2) influence on the national legislation of Ukraine of the defining features of the Romano-Germanic legal family, namely: hierarchical (vertical) and sectoral (horizontal) structure of legislation, its codified, systematized, ordered and unified character;

3) reception of legal institutions (borrowing of legal innovations that have been tested in other countries) while preserving the national legal tradition and culture;

4) development of the national legislation of Ukraine under the influence of international law, first of all, the law of the European Union (internationalization of the law, adaptation of the national legislation of Ukraine to the law of the European Union).

\section{Bibliographic references}

Beinoravicius, D. (2018). Globalization and Law. Logos (Lithuania), 3. Recovered from http://litlogos.eu/L94/Logos_94_023_032_B einoravicius.pdf.

Biriukova, A.M. (2018). Legal globalization: to define the concept. Scientific Bulletin of Public and Private Law, 1(1), pp. 3-7. Recovered from http://nvppp.in.ua/vip/2018/1/tom_1/3.pdf.

Biryokov, R.M. (2009). Globalization and its influence on legal sphere. Comparative legal researches, number 2, pp. 36-40.

Biryokov, R.M. (2011). National Legal system in conditions of globalisation (main directions of transformation): manuscript. Odesa: International Humanitarian University.

Hapotii, V.D., Zhyltsov, O.L. \& Vorzhevitina, H.I. (2019). Basic legal systems of the world: a textbook. Melitopol.

Homonai, V.V. (2012). Reception of law in the conditions of european integration processes.
Uzhhorod National University Herald. Series: Law, issue 18, pp. 9 -12.

Khaustova, M.H. (2013). The tendency of universalization and unification of law as one of the directions of influence of globalization on national legal system. Theory and practice of jurisprudence, issue 2. Recovered from https://dspace.nlu.edu.ua/bitstream/1234567 89/6065/1/Xaystova.pdf.

Khaustova, M.H. (2015). Theoretical and legal foundations of transformation of the legal systems of Ukraine in the context of globalization. Comparative and analytical law, number 4, pp. 53-55.

Luts, L.A. (2005). The European Intergovernmental Legal Systems: general theoretic characteristics: manuscript. Kyiv: V.M. Koretsky Institute of state and law of National Academy of Sciences of Ukraine.

Mernyk, A.M. \& Burlakov, B.M. (2019). Ukrainian national legal system in the context of globalization processes. Juridical Scientific and Electronic Journal, 6, pp. 37-41. Recovered from http://www.lsej.org.ua/6_2019/8.pdf.

Ministry of Foreign Affairs of Ukraine. (2019a). The European Commission "For Democracy through Law". Recovered from https://mfa.gov.ua/mizhnarodnividnosini/rada-yevropi/yevropejskakomisiya-za-demokratiyu-cherez-pravo.

Ministry of Foreign Affairs of Ukraine (2019b). Ukraine's participation in the activities of the Council of Europe Recovered from https://mfa.gov.ua/mizhnarodnividnosini/rada-yevropi/uchast-ukrayini-udiyalnosti-radi-yevropi.

Moroz, O.B. (2020). Problems of adaptation of Ukrainian legislation to EU legislation. Almanac of international law, 23, pp. 180-186.

Nastasyak, I. Yu. (2014). Interaction of modern legal systems of the world in terms of the globalization. Scientific Bulletin of the International Humanities University. Series: Jurisprudence, vol 7, pp. 35 - 37.

Nykytyna, N.K. (2008). Russian legislation in the context of globalization: (questions of theory and practice): manuscript. Moscow: Institute of State and Law of the Russian Academy of Sciences.

Permanent Representation of Ukraine to the Council of Europe (2020). Ukraine and the European Commission for Democracy through Law. Recovered from https://coe.mfa.gov.ua/en/partnership/ukrain e-and-european-commission-democracythrough-law. 
Petryshyn, O.V. (Ed.). (2015). Theory of state and law: textbook. Kharkiv: Law.

Rasskazov, L.P. (2015). Globalization and its impact on modern Russian law. Polythematic Network Electronic Scientific Journal of the Kuban State Agrarian University, number 111, pp. 192-211. Recovered from https://cyberleninka.ru/article/n/globalizatsiy a-i-ee-vliyanie-na-sovremennoe-rossiyskoepravo.

Ryndiuk, V.I. (2019). Legislation as a hierarchic system of decisions of normative content of public authorities. Visegrad Journal on Human Rights, 5, pp. 118-122.

Ryndiuk, V.I. (2021). Ordering of the legislation of Ukraine: theoretical-methodological and technical-legal aspects: monograph. Kyiv: National Economic University named after Vadym Hetman.

Shulzhenko, F.P. (2007). Social-lawful state in Ukraine: problems of formation and modernization: monograph. Kyiv: National Economic University named after Vadym Hetman.

Sobkova, V.V. (2012). The impact of globalization on the legal system of Ukraine. Universidad Nacional de Aviación. Recovered from https://er.nau.edu.ua/handle/NAU/13890.

Vaganova, O., Rudenko, I., Markova, S., Smirnova, Z., \& Kutepov, M. (2019). The use of educational video materials in educational process of a higher educational institution. Amazonia Investiga, 8(22), 216-222.
Retrieved from https://amazoniainvestiga.info/index.php/am azonia/article/view/308

Vovk, D. O. (2012). Legal tradition: understanding in the context of correlation with legal system and legal culture. Journal of the National Academy of Legal Sciences of Ukraine, number 2(69), pp. 42-52.

Westbrook, D. A. (2006). The globalization of American law. Theory, Culture \& Society, 23(2-3), pp. 526-528. Recovered from https://doi.org/10.1177/02632764060230029 7.

Yushchyk, O.I. (2013). Dialectics of Law. Kyiv: Editorial Board of the magazine "Law of Ukraine"; In Jure. Recovered from https://sites.google.com/view/lawacademy2021/\%D0\%B4\%D0\%B8\%D0\%B0 $\% \mathrm{D} 0 \% \mathrm{BB} \% \mathrm{D} 0 \% \mathrm{~B} 5 \% \mathrm{D} 0 \% \mathrm{BA} \% \mathrm{D} 1 \% 82 \% \mathrm{D}$ 0\%B8\%D1\%87\%D0\%B5\%D1\%81\%D0\%B A\%D0\%B0\%D1\%8F-

$\% \mathrm{D} 1 \% 88 \% \mathrm{D} 0 \% \mathrm{BA} \% \mathrm{D} 0 \% \mathrm{BE} \% \mathrm{D} 0 \% \mathrm{BB} \%$ D0\%B0$\% \mathrm{D} 0 \% \mathrm{BF} \% \mathrm{D} 1 \% 80 \% \mathrm{D} 0 \% \mathrm{~B} 0 \% \mathrm{D} 0 \% \mathrm{~B} 2 \% \mathrm{D}$ $0 \% \mathrm{~B} 0$.

Yushchyk, O.I. (2016). Crisis of law understanding and the dialectic theory of law. Law of Ukraine, 3, pp. 258-265.

Zavalnyi, A.M., Tiurina, O.V., Kryvytskyi, Y.V. \& Pidvysotskyi, V.V. (2017). Multimedia textbook "Legal systems of today". National Academy of Internal Affairs, Recovered from https://arm.naiau.kiev.ua/books/legal_compa rativistics. 